\title{
KAJIAN YURIDIS MEMORANDUM OF UNDERSTANDING DALAM PENYELENGGARAAN PERJANJIAN KERJASAMA DAERAH BERDASARKAN PP NO. 28 TAHUN 2018 TENTANG KERJASAMA DAERAH*
}

\author{
Sai’da Rusdiana** dan Rizky Septiana Widyaningtyas $^{* * *}$ \\ Departemen Hukum Perdata dan Departemen Hukum Administrasi Hukum \\ Fakultas Hukum Universitas Gadjah Mada \\ Jalan Sosio Justisia No. 1, Bulaksumur, Sleman, D.I. Yogyakarta 55281
}

\begin{abstract}
This study aims to determine and examine the position of Memorandum of Understanding (MoU) in the implementation of regional cooperation agreements based on Government Regulation No. 28 of 2018 concerning Regional Cooperation and understanding of stakeholders regarding the nature of MoU in Regional Cooperation Agreements. This study uses empirical juridical research methods. This research was conducted by examining primary data and secondary data which will then be analyzed qualitatively to answer the issues raised. MoU must be made as a condition to be able to make regional cooperation agreements based on the mandate of Article 6 paragraph (1) Government Regulation No. 28 of 2018 concerning Regional Cooperation where one of the stages that must be passed is the preparation and signing of a collective agreement. The MoU has a control function from the Regional Head towards the implementation of regional cooperation, given the legal relationship that arises in the implementation of regional dimensions of public cooperation based on consideration of the efficiency and effectiveness of public services and mutual benefit to the parties.
\end{abstract}

Keywords: memorandum of understanding, regional cooperation.

\section{Intisari}

Penelitian ini bertujuan untuk mengetahui dan mengkaji kedudukan Memorandum Of Understanding (MoU) dalam penyelenggaraan perjanjian kerjasama daerah berdasarkan Peraturan Pemerintah No. 28 Tahun 2018 Tentang Kerjasama Daerah serta pemahaman bagi pemangku kebijakan mengenai hakikat MoU dalam Perjanjian Kerjasama Daerah. Penelitian ini menggunakan metode penelitian yuridis empiris. Penelitian ini dilakukan dengan mengkaji data primer dan data sekunder yang kemudian dianalisis secara kualitatif untuk menjawab permasalahan yang diangkat. MoU wajib dibuat sebagai syarat untuk dapat membuat perjanjian kerjasama daerah berdasarkan amanat Pasal 6 ayat (1) Peraturan Pemerintah No. 28 Tahun 2018 Tentang Kerjasama Daerah dimana salah satu tahapan yang harus dilalui adalah penyusunan dan penandatanganan kesepakatan bersama. MoU memiliki fungsi kontrol dari Kepala Daerah terhadap penyelengaraan kerjasama daerah, mengingat hubungan hukum yang timbul dalam penyelenggaraan kerjasama daerah berdimensi publik yang didasarkan pada pertimbangan efisiensi dan efektivitas pelayanan publik serta saling menguntungkan para pihak.

Kata Kunci: memorandum of understanding, kerjasama daerah.

\section{Pokok Muatan}

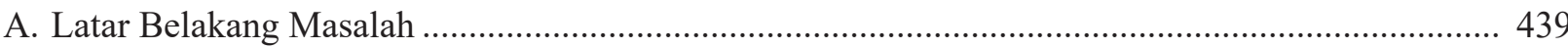

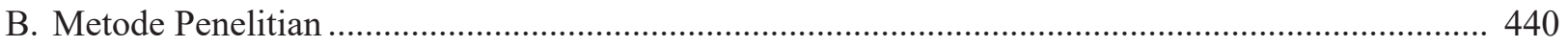

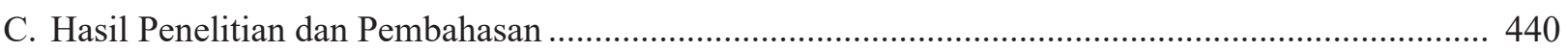

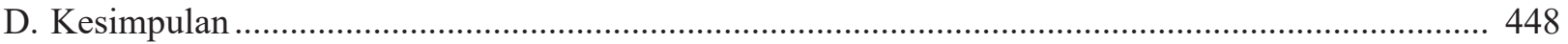

Hasil Penelitian Peningkatan Kapasitas Peneliti Dosen Muda Tahun 2018.

**Alamat korespondensi: saida_rusdiana@ugm.ac.id

*** Alamat korespondensi: rizkyseptiana@ugm.ac.id. 


\section{A. Latar Belakang Masalah}

Kerjasama Daerah didasarkan pada perjanjian sebagai dasar hubungan hukum antara Pemerintah Daerah dengan mitra kerjasama. Tata cara kerjasama daerah telah diatur secara teknis dalam Peraturan Menteri Dalam Negeri Nomor 22 Tahun 2009 tentang Petunjuk Teknis Kerja Sama Daerah (Permendagri 22/2009). Dalam Lampiran I Permendagri 22/2009 diuraikan secara jelas tahapan-tahapan yang harus dilalui dalam kerjasama antar-daerah, seperti tahap persiapan yaitu pembentukan Tim Koordinasi Kerja Sama Daerah (TKKSD), tahap penawaran, pembuatan dan penandatanganan kesepakatan bersama atau Memorandum of Understanding (selanjutnya disebut MoU), penyusunan dan penandatanganan perjanjian kerjasama dan yang terakhir adalah pelaksanaan perjanjian kerjasama.

Jika dilihat dalam Lampiran I Permendagri 22/2009 secara tegas mencantumkan pembuatan dan penandatangan $\mathrm{MoU}$ sebagai tahapan yang wajib dilaksanakan dalam kerjasama daerah. Kewajiban untuk membuat MoU sebelum membuat perjanjian kerjasama diperkuat oleh Pasal 6 ayat (1) Peraturan Pemerintah Nomor 28 Tahun 2018 tentang Kerjasama Daerah (PP 28/2018) yang menyatakan bahwa Penyelenggaraan KSDD dilakukan melalui tahapan:
a. persiapan;
b. penawaran;
c. penyusunan kesepakatan bersama;
d. penandatanganan kesepakatan bersa- ma;
e. persetujuan Dewan Perwakilan Rakyat Daerah;
f. penyusunan perjanjian kerja sama;
g. penandatanganan perjanjian kerja sama;.

Berkaitan dengan kesepakatan bersama atau MoU jika ditinjau dari ranah hukum privat, sesungguhnya tidak wajib untuk dibuat oleh para pihak yang akan mengikatkan diri dalam perjanjian. MoU merupakan kesepakatan bersama, yang dibuat dengan tujuan memberikan kesempatan kepada para pihak untuk mengadakan studi kelayakan terlebih dahulu sebelum membuat perjanjian yang lebih terperinci dan mengikat para pihak pada nantinya. ${ }^{1}$ Eksistensi dari MoU sendiri tidak memiliki akibat hukum yang mengikat para pihak untuk melaksanakannya serta tidak ada sanksi jika para pihak tidak melaksanakan. Hal ini berbeda dengan perjanjian yang memang memiliki akibat hukum yang memaksa untuk dilaksanakan oleh para pihak yang membuatnya layaknya undang-undang.

Salah satu contoh daerah yang telah menyelenggarakan kerjasama daerah yaitu Pemerintah Kota Surakarta. Berkaitan dengan perjanjian kerjasama yang selama ini telah dibuat oleh Pemerintah Kota Surakarta masih berpedoman pada kebiasaan yang diterapkan di lingkungan setempat. Pemahaman yang muncul dalam penyelenggaraan kerjasama daerah adalah pasti harus ada kesepahaman terlebih dahulu yang diwujudkan secara tertulis dalam sebuah MoU. Setelah dibuat MoU barulah ada kesepakatan para pihak yang diwujudkan secara tertulis dalam Memorandum of Agreement (MoA).

Dengan demikian, dapat dikatakan bahwa MoU menjadi sesuatu tahapan yang harus ada sebelum membuat perjanjian kerjasama. Bahkan dalam Raperda yang disusun oleh Pemerintah Kota Surakarta dengan tegas mencantumkan ketentuan mengenai pembuatan $\mathrm{MoU}$ sebelum membuat perjanjian kerjasama. Oleh karena itu, penting untuk mengkaji 2 (dua) hal yaitu: (1) bagaimana kedudukan MoU dalam penyelenggaraan perjanjian kerjasama daerah berdasarkan Peraturan Pemerintah No. 50 Tahun 2007 Tentang Tata Cara Pelaksanaan Kerjasama Daerah?; dan (2) bagaimana hakikat MoU dalam Perjanjian Kerjasama Daerah? 


\section{B. Metode Penelitian}

Sifat penelitian yang digunakan adalah penelitian hukum atau yuridis yang terdiri dari penelitian yuridis normatif dan penelitian yuridis empiris. Penelitian yuridis normatif atau penelitian hukum normatif adalah penelitian yang meletakkan hukum sebagai sebuah bangunan sistem norma, yang terdiri dari asas-asas, norma, kaidah dari peraturan perundangan, putusan pengadilan, perjanjian serta doktrin (ajaran). ${ }^{2}$ Pendekatan yang digunakan dalam penelitian hukum normatif ini adalah pendekatan perundang-undangan (statute approach) dan pendekatan konseptual (conceptual approach). Pendekatan perundang-undangan dilakukan dengan menelaah semua peraturan perundang-undangan yang berkaitan dengan kerja sama daerah, karena sifat hukum yang memiliki ciriciri chomprehensif, all-inclusive, dan systematic. ${ }^{3}$ Pendekatan ini digunakan untuk mengidentifikasi dan memetakan peraturan perundang-undangan apa saja yang berkaitan dengan kerja sama daerah, serta koherensi dan konsistensi pengaturannya. Pendekatan konseptual, diperlukan untuk menemukan pemikiran atau ide yang melahirkan konsep-konsep kunci mengenai pemaknaan $\mathrm{MoU}$ baik dari perspektif hukum privat (hukum perdata) maupun dari perspektif hukum publik (hukum administrasi negara). Sementara penelitian yuridis empiris dilakukan untuk memperoleh data primer di lapangan guna mengkonfirmasi pelaksanaan dari suatu perundang-undangan.

\section{Hasil Penelitian dan Pembahasan}

1. Kedudukan MoU dalam Penyelenggaraan Perjanjian Kerjasama Daerah berdasarkan PP No. 28 Tahun 2018 Tentang Kerjasama Daerah

Menurut aspek hukum privat, yakni pada Pasal 6 ayat (1) Peraturan Pemerintah No. 28 Tahun
2018 Tentang Kerjasama Daerah menyatakan bahwa Penyelenggaraan KSDD dilakukan melalui tahapan:
a. persiapan;
b. penawaran;
c. penyusunan kesepakatan bersama;
d. penandatanganan kesepakatan bersama;
e. persetujuan Dewan Perwakilan Rakyat Daerah;
f. penyusunan perjanjian kerja sama;
g. penandatanganan perjanjian kerja sama;

Berkaitan dengan kesepakatan bersama atau MoU jika ditinjau dari ranah hukum privat, sesungguhnya tidak wajib untuk dibuat oleh para pihak yang akan mengikatkan diri dalam perjanjian. Secara keseluruhan tidak ada standarisasi dalam pembuatan MoU, hanya saja tunduk pada ketentuan yang ada dalam peraturan, yakni yang termuat dalam ketentuan pokok-pokok yang harus ada dalam kesepakatan bersama dalam Peraturan Menteri Dalam Negeri Nomor 22 Tahun 2009 Tentang Petunjuk Teknis Tata Cara Kerja Sama Daerah dan PP Kerja Sama Daerah. ${ }^{4}$

Berkenaan dengan wajib atau tidak dibuatnya MoU sebagai nota kesepahaman atau kesepakatan tersebut tidak ada pengaturan dalam KUHPerdata. Namun dalam beberapa perjanjian yang berdimensi publik seperti halnya perjanjian kerjasama daerah, terdapat ketentuan yang mewajibakan untuk dibuatnya MoU sebelum dibuat perjanjian kerjasama daerah. Kewajiban untuk membuat MoU disini dapat diartikan sebagai suatu syarat dalam penyelenggaraan kerjasama daerah karena harus dipenuhi. Dalam hukum perdata dikenal istilah perikatan bersyarat. Perikatan ini baru akan lahir apabila syarat terpenuhi atau dikenal dengan perikatan dengan syarat tangguh. Dengan demikian MoU sebagai suatu syarat tangguh wajib dibuat

Mukti Fajar dan Yulianto Achmad, 2013, Dualisme Penelitian Hukum Normatif dan Empiris, Pustaka Pelajar, Yogyakarta, hlm.34. Comprehensive, artinya norma-norma hukum yang ada saling terkait sat sama lain secara logis; al., inclusive, artinya kumpulan norma hukum tersebut cukup mampu menampung permasalahan hukum yang ada; dan systematic artinya bahwa norma hukum tersusun secara hierarkis. Lebih lanjut baca : Mukti Fajar dan Yulianto Achmad, 2013, Dualisme Penelitian Hukum Normatif dan Empiris, Pustaka Pelajar, Yogyakarta, hlm. 185 .

4 Hasil wawancara dengan Ibu Tri Idawati, Kasub Kerja Sama Dalam Negeri, Pemda Surakarta, tanggal 3 September 2018. 
sebelum para pihak membuat perjanjian kerjasama daerah.

Perjanjian kerjasama daerah tunduk pada ketentuan hukum perjanjian yang diatur dalam KUHPerdata. Berkenaan dengan keabsahan perjanjian juga mengacu pada ketentuan Pasal 1320 KUHPerdata, dimana terkandung adanya kesepakatan, kecakapan para pihak, suatu hal tertentu dan causa yang halal. Ada tiga fase dalam kontrak yaitu pra kontraktual, kontraktual dan post kontraktual. Pada fase pra kontraktual, para pihak melakukan negosiasi untuk mempertemukan kehendak mereka. Dalam tahap ini para pihak juga dapat membuat nota kesepakatan atau sering pula disebut Memorandum of Understanding (MoU).

$\mathrm{MoU}$ adalah dasar penyusunan kontrak pada masa datang yang didasarkan pada hasil permufakatan para pihak, baik secara tertulis maupun lisan. ${ }^{5}$ Nota kesepahaman yang dibuat antara subjek hukum yang satu dengan subjek hukum lainnya, baik dalam suatu negara maupun antarnegara untuk melakukan kerja sama dalam berbagai aspek kehidupan dan jangka waktunya tertentu. ${ }^{6}$ Berdasarkan pengertian tersebut, MoU bukanlah suatu perjanjian melainkan suatu bentuk kesepahaman para pihak yang dituangkan secara tertulis sebelum mereka menindaklanjuti dengan membuat sebuah perjanjian. Dengan demikian MoU tidak memiliki daya mengikat seperti halnya perjanjian. Syarat untuk adanya kesepakatan sudah ada disini namun bukan sepakat dalam perjanjian melainkan kesepakatan kehendak bersama untuk nantinya akan membuat perjanjian.

Jika dikaitkan dengan ketentuan dalam Pasal 1320 KUHPerdata maka MoU tidak memenuhi syarat sah perjanjian yaitu suatu hal tertentu. Apa yang menjadi objek dalam MoU hanya berisi halhal yang umum saja. Substansi dari MoU berupa kesepakatan atau kesepahaman mengenai sesuatu yang nantinya akan ditindaklanjuti dengan membuat kesepakatan yang dituangkan dalam perjanjian tertulis.

MoU bukanlah sebuah perjanjian sehingga tidak memiliki kekuatan mengikat layaknya perjanjian. MoU sesungguhnya merupakan perikatan moral sehingga tidak memiliki akibat hukum (gentlement agreement). Perikatan moral tidak terkandung hak dan kewajiban di dalamnya sehingga tidak memiliki hak gugat. Jika ada pelanggaran terhadap isi $\mathrm{MoU}$ atau tidak melaksanakan MoU maka tidak ada sanksi hukum yang bisa dijatuhkan kepada para pihak. Dalam hal ini para pihak tidak dapat dikatakan melakukan wanprestasi dengan demikian tidak dapat dituntut dimuka hakim.

Salah satu ciri yang terkandung dalam $\mathrm{MoU}$ adalah memiliki jangka waktu berlakunya. Jangka waktu ini bertujuan untuk memberikan kesempatan bagi para pihak menindaklanjuti membuat perjanjian. Namun tidak terkandung adanya kewajiban yang mengikat untuk menindaklanjuti dengan pembuatan perjanjian. Dalam jangka waktu tersebut para pihak memang seyogyanya menindaklanjuti dengan membuat suatu perjanjian. Apabila jangka waktu MoU telah habis dan para pihak tidak menindaklanjuti dengan membuat perjanjian maka perjanjian tidak bisa dibuat, kecuali MoU tersebut telah diperpanjang kembali.

Perlu dipahami bahwa MoU bukanlah perjanjian induk meskipun keberadaannya menjadi syarat untuk lahirnya perjanjian kerjasama daerah. Dalam perjanjian yang berunsur publik memang harus memperhatikan ketentuan hukum pemaksa seperti halnya ketentuan dalam Peraturan Pemerintah No. 28 Tahun 2018 Tentang Kerjasama Daerah dan Permendagri No. 22 Tahun 2009 tentang Petunjuk Teknis Kerja sama Daerah. Ketentuan yang bersifat imperatif ini tidak bisa disimpangi dengan kesepakatan para pihak.

Menurut aspek hukum publik. Asas 
desentralisasi dalam penyelenggaraan pemerintahan di Indosenia berimplikasi adanya kewenangan pemerintah diserahkan kepada daerah otonom dan daerah otonom diberi kewenangan untuk mengatur dan mengurus urusannya sendiri. Hal ini dihadapkan pada kondisi daerah yang berbedabeda, karena masing-masing memiliki potensi dan keterbatasan. Keterbatasan pemerintah daerah dalam melaksanakan pembangunan dan memberikan pelayanan publik yang menjangkau seluruh masyarakat berpotensi menyebabkan ketimpangan pemerataan hasil pembangunan dan pelayanan publik. ${ }^{7}$ Tidak jarang masyarakat lebih dekat dan lebih mudah mengakses daerah lain daripada ke ibukotanya sendiri, sehingga berbagai kebutuhan dasarnya seringkali juga terpenuhi dari daerah tetangganya. ${ }^{8}$ Kerjasama daerah diharapkan mampu mengurangi kesenjangan daerah dalam penyediaan pelayanan umum, meningkatkan kesejahteraan dan sumber pendapatan asli daerah. ${ }^{9}$ Selain itu, kerjasama daerah juga diselenggarakan untuk pemerataan hasil pembangunan.

Kerjasama daerah diatur dalam Peraturan Pemerintah Nomor 28 Tahun 2018 tentang Kerja Sama Daerah. Penjelasan umum PP a quo menjelaskan bahwa Kerja Sama Daerah memiliki tujuan atau maksud, antara lain sebagai sarana untuk menetapkan hubungan daerah satu dengan yang lainnya dalam kerangka Negara Kesatuan Republik Indonesia, menyerasikan pembangunan daerah, menyinergikan potensi antardaerah, daerah dengan pihak ketiga dan daerah dengan pemerintah daerah atau lembaga di luar negeri serta meningkatkan pertukaran pengetahuan, teknologi dan kapasitas fiskal kerja. ${ }^{10}$

Kerjasama Daeah ini dituangkan dalam bentuk perjanjian, dalam hal ini yang dilakukan oleh daerah otonom sebagai badan hukum publik.
Kerja sama daerah sebagai pelaksanaan ketentuan Pasal 197 Undang-Undang Nomor 32 Tahun 2004 tentang Pemerintah Daerah ditutur oleh Peraturan Pemerintah Nomor 50 Tahun 2007 tentang Tata Cara Pelaksanaan Kerja Sama Daerah yang dewasa ini diubah dalam Peraturan Pemerintah Nomor 28 Tahun 2018 tentang Kerja Sama Daerah sebagai pelaksanaan ketentuan Pasal 369 Undang-Undang Nomor 23 Tahun 2014 tentang Pemerintah Daerah. Perubahan aturan induknya yaitu aturan tentang Pemerintah Daerah berakibat pula diubahnya peraturan mengenai kerja sama daerah.

Pengertian Kerja Sama Daerah mengalami perubahan, yang semula berupa kesepakatan, kini menjadi usaha bersama. Adapun kerja sama daerah menurut Pasal 1 angka 1 Peraturan Pemerintah Nomor 28 Tahun 2018 tentang Kerja Sama Daerah, yaitu:

"usaha bersama antara daerah dan daerah lain, antara daerah dan pihak ketiga, dan/ atau antara daerah dan lembaga atau pemerintah daerah di luar negeri yang didasarkan pada pertimbangan efisiensi dan efektivitas pelayanan publik serta saling menguntungkan.",

Oleh karenanya, berdasarkan uraian di atas, dapat ditarik unsur-unsur dari kerja sama daerah, yaitu:
a. Merupakan usaha bersama;
b. Antara daerah dan daerah lain(KSDD);
c. Antara daerah dan pihak ketiga (KSDPK);
d. Antara daerah dan lembaga atau;
e. Pemerintah daerah di luar negeri;
f. didasarkan pada pertimbangan efisiensi dan efektivitas pelayanan publik serta saling menguntungkan

Kerjasama Daerah yang dikenal dalam ketentuan Peraturan Pemerintah Nomor 28 Tahun

\footnotetext{
Andi Wahyudi dan Maria AP. Sari, "Kerjasama Antardaerah Untuk Meningkatkan Pembangunan Daerah Dan Pelayanan Publik Di Kawasan Perbatasan”, Jurnal Borneo Administrator, Vol. 7 No. 3 Tahun 2011, hlm. 284.

Ibid.

Penjelasan Umum Atas Peraturan Pemerintah Republik Indonesia nomor 50 Tahun 2007 tentang Tata Cara Pelaksanaan Kerjasama Daerah (Lembaran Negara Republik Indonesia Thun 2007 Nomor 112, Tambahan Lembaran Negara Republik Indonesia Nomor 4761).

10 Lihat penjelasan umum atas Peraturan Pemerintah Nomor 28 Tahun 2018 tentang Kerja Sama Daerah (Lembaran Negara Republik Indonesia Tahun 2018 Nomor 97, Tambahan Lembaran Negara Republik Indonesia Nomor 6219).
} 
2018 tentang Kerja Sama Daerah terdiri dari : Kerja Sama Daerah Dengan Daerah Lain (KSDD); Kerja Sama Daerah Dengan Pihak Ketiga (KSDPK); Kerja Sama Daerah Dengan Pemerintah Daerah di Luar Negeri (KSDPL); dan Kerja Sama Daerah Dengan Lembaga di Luar Negeri (KSDLL). Tahapan atau tata cara Kerjasama Daerah secara garis besar diselenggarakan sebagai berikut : ${ }^{11}$

Pertama, tahap persiapan. Dalam tahap ini, pemerintah membentuk Tim Koordinasi Kerja Sama Daerah (TKKSD). Pemerintah akan melakukan inventarisasi objek kerja sama yang akan dikerjasakan dengan berpedoman kepada Rencana Pembangunan Jangka Menengah Daerah (RPJMD) dan apabila belum ada di RPJMD, maka berpedoman pada Rencana Kerja Pembangunan Daerah (RKPD) sesuai dengan prioritas. Adapun persiapan yang dimaksud: (1) Menyusun rencana kerja sama terhadap objek yang akan dikerjasamakan dengan daerah lain; (2) Menyiapkan informasi dan data yang lengkap mengenai objek yang akan dikerjasamakan; dan (3) Analisis mengenai manfaat dan biaya kerja sama.

Kedua, adalah tahap penawaran. Setelah menentukan prioritas dan memilih daerah, serta objek yang akan dikerjasamakan, maka tahap selanjutnya adalah melakukan penawaran, yang sekurang-kurangnya memuat: (1) Objek yang dikerjasamakan; (2) Manfaat kerja sama terhadap pembangunan daerah; (3) Bentuk kerja sama; (4) Tahung anggaran dimulainya kerja sama; (5) Jangka waktu kerja sama. Dengan dilampirkan informasi dan data yan dapat berupa kerangka acuan/proposal objek yang akan dikerjasamakan.

Ketiga adalah tahap penyiapan kesepakatan. Setelah penawaran disetujui/telah menerima jawaban persetujuan, TKKSD masing-masing pihak membahas mengenai rencana Kerja Sama Antar Daerah (KSAD) dan menyiapkan Kesepakatan Bersama, yang pada pokok-pokoknya memuat: (1) Identitas para pihak; (2) Maksud dan tujuan; (3)
Objek dan ruang lingkup kerja sama; (4) Bentuk kerja sama; (5) Sumber biaya; (6) Tahun anggaran dimulainya pelaksanaan kerja sama; (7) Jangka waktu berlakunya kesepakatan berssama, paling lama 12 bulan; dan (7) Rencana kerja, yang memuat: (i) Jangka waktu penyususnan rencana perkankian kerja sama oleh masing-masing TKKSD; (ii) Tanggal pembahasan bersama rancangan perjanjian kerja sama oleh TKKSD masing-masing; (iii) Jadwal penandatanganan perjanjian KSAD; dan (iv) Rencana kerja tersebut dijadikan lampiran dalam kesepakatan bersama dan ditandatangani oleh masing-masing kepala daerah.

Keempat adalah tahap penandatanganan kesepakatan. Kesepakatan bersama antar daerah yang sudah siap ditandatangani oleh masing-masing Kepala Daerah, yang dilaksanakan sesuai dengan kesepakatan para pihak dan dapat disaksikan oleh Menteri Dalam Negeri dan menteri/Pimpinan LPND yang terkait dengan objek kerja sama. Kelima adalah tahap penyiapan perjanjian. Selanjutnya, masing-masing TKKSD masing-masing daerah mempersiapkan rancangan perjanjian kerja sama yang sekurang-kurangnya memuat: (1) Subjek kerja sama; (2) Objek kerja sama; (3) Ruang lingkup kerja sama; (4) Hak dan kewajiban; (5) Jangka waktu kerja sama; (6) Keadaan memaksa/force majure; (7) Penyelesaian penyelisihan; dan (8) Pengakhiran kerjasama. Dalam penyusunan rencana kesepakatan dapat meminta bantuan ahli/pakar dan/atau berkonsultasi dengan Departemen Dalam negeri dan Departemen/Lembaga Pemerintah Non Departemen terkait. Setelah ada kesepakatan, Ketua TKKSD masing-masing daerah memberikan paraf pada rancangan akhir KSAD dan menyerahkannya kepada masing-masing Kepala Daerah untuk ditandatangani.

Keenam adalah tahap penandatanganan perjanjian. Perjanjian kerja sama antar daerah selanjutnya ditandatangani oleh Kepala Daeah pada waktu dan tempat yang telah disepakati oleh

\footnotetext{
11 Lihat Pasal 3 ayat (2) Peraturan Menteri Dalam Negeri Nomor 22 Tahun 2009 Tentang Petunjuk Teknis Tata Cara Kerja Sama Daerah.
} 
para pihak. Ketujuh adalah tahap pelaksanaan. Pelaksanaan kerja sama daerah harus memperjatikan rencanakerja yang telah disepakati. Dalamperjanjian KSAD yang jangka waktunya lebih dari 5 (lima) tahun dan sesuai kesepakatan dapat membentuk Badan Kerja Sama Daerah yang memiliki tugas: (1) Melakukan pengelolaan, monitoring dan evaluasi atas pelaksanaan KSAD; dan (2) Memberikan masukan dan saran kepada Kepala Daerah masingmasing mengenai langkah-langkah yang harus dilakukan apabila ada permasalahan.

Biaya pelaksanaan KSAD dan/atau Badan Kerja Sama Daerah menjadi tanggungjawab Satuan Kerja Perangkat Daerah (SKPD) masing-masing. Apabila dalam pelaksanaanya terdapat perubahan yang menyebabkan penambahan pembebanan APBD maka perlu dimintakan persetujuan DPRD dan memberikan informasi kepada DPRD jika terdapat keadaan memaksa/force majure. Di 3 (tiga) bulan sebelum berakhirnya perjanjian KSAD, masing-masing SKPD yang melakukan KSAD dibantu badan Kerja Sama dan didampingi oleh tim penilai eksternal untuk melakukan inventarisasi dan penilaian secara finansial terhadap: Pertama, barang bergerak dan tidak bergerak terkait perjanjian KSAD. Terhadap barang-barang ini pembagiannya dapat dilaksanakan dengan menjualnya kepada para pihak yang melakukan KSAD dan menjual melalui lelang terbuka. Lalu, hasil penjualan dikurangi utang atau kewajiban yang jadi beban KSAD dan dibagi berdasarkan pertimbangan hak dan kewajiban.

Kedua, kewajiban atau utang yang menjadi beban KSAD. Salah satu tahap yang disyaratkan dalam pembuatan kerjasama daerah sebagaimana diatur dalam PP Nomor 28 Tahun 2018, adalah penyiapan dan penandatanganan kesepakatan atau sering disebut dengan MoU. Kesepakatan atau MoU dimaksud memuat hal-hal yang bersifat umum, sebagai pendahuluan sebelum dibuat perjanjian kerjasama. Sebagaimana telah dijelaskan dalam bagian sebelumnya, dalam perspektif hukum kontrak/perjanjian, secara teoritis MoU memiliki sifat yang tidak mengikat dan harus ditindaklanjuti dengan perjanjian supaya mempunyai kekuatan mengikat. MoU bukanlah perjanjian, kedudukannya hanyalah sebagai kesepakatan pendahuluan sehingga tidak melahirkan hak dan kewajiban. Sebagai konsekuensinya, jika muatan MoU tidak dilaksanakan oleh para pihak, tidak akan menimbulkan akibat hukum. Mengingat karakteristik yang dimiliki oleh $\mathrm{MoU}$ tersebut, kemudian menjadi pertanyaan mengapa dalam pelaksanaan kerjasama daerah mensyaratkan adanya MoU sebelum ditandatangi perjanjian kerjasama.

Dalam perspektif Hukum Administrasi Negara, pemerintah dalam melakukan suatu tindakan atau perbuatan hukum sering tampil dalam dua kedudukan hukum yang berbeda atau disebut dengan dengan istilah dua kepala (twe patten), sebagi wakil dari jabatan (ambt) tunduk pada hukum publik dan wakil dari badan hukum (rechtsperson) tunduk pada hukum privat. ${ }^{12}$ Perbuatan pemerintah dalam bidang hukum publik merupakan tindakan hukum sepihak yang dilakukan oleh pemerintah dan khusus melaksanakan tugas-tugas pemerintahan berdasarkan wewenang yang luar biasa. Dengan demikian unsur-unsur perbuatan hukum pemerintah yang tunduk dalam hukum publik disimpulkan oleh S. Prajudi Atmosudirdjo sebagaimana dikutip oleh Safri Nugraha dkk, yaitu sebagai berikut ${ }^{13}$ : Pertama, sebagai tindakan hukum, yang melahirkan hak dan kewajiban. Kedua, bersifat seihak, yaitu tindakan itu harus mengatur dan memaksa, tindakan hukum tersebut dilaksanakan sepihak oleh pemerintah dalam bentuk yang ditetapkan penangannya oleh kekuatan hukum yang mengikatnya. Ketiga, berkaitan dengan bidang pemerintahan, sehingga tidak dapat merambah ke bidang lain (legislatif dan/atau yudikatif), walaupun dalam praktik ketiga kekuasaan tersebut sulit dipisahkan secara tegas.

12 Muhammad Yakim, "Kedudukan Hukum Pemerintah Daerah Dalam Kerjasama Daerah Dengan Pihak Ketiga”, Jurnal Katalogis, Volume 5 Nomor 7, Juli 2017, hlm 80-88.

13 Safri Nugraha, et all, 2007, Hukum administrasi Negara, Center for Law and Good Governance Studies (CLGS) Fakultas Hukum Indonesia, Depok, hlm.88-89. 
Keempat, berdasarkan kewenangan yang luar biasa, maksudnya kekuasaan diperoleh dari undangundang yang tidak diberikan pada badan swasta (Prins).

Tindakan pemerintah dalam bidang hukum publik dapat dibagi menjadi dua bagian, yaitu ${ }^{14}$ : Pertama, tindakan pemerintah atau administrasi negara bersegi dua (tweezijdge publiek rechtelijke handelingen). Perbuatan ini mengacu pada perbuatan hukum bersedi dua yaitu perjanjian, di mana terdapat persesuaian kehendak antara dua pihak yang diatur oleh hukum yang istimewa, yaitu peraturan hukum publik, bukan diatur dalam hukum biasa atau KUHPerdata. Sebagai contoh adalah kortverband contract, yaitu perjanjian kerja jangka pendek di lingkungan tenaga asing. Kontrak antara maskapai minyak asing dengan pemerintah berdasarkan Undang-Undang Nomor 1 tahun 1967 tentang Penanaman Modal Asing. Kedua, perbuatan pemerintah atau administrasi negara yang bersegi satu. (eenzijdige publiek rechtelijke handelingen). Dalam bidang ini perbuatan pemerintah menghasilkan beberapa keputusan dalam arti luas, berupa peraturan, rencana, norma jabaran, legislasi semu, dan penetapan.

Di sisi lain, pemerintah atau administrasi negara dimungkinkan membuat hubungan hukum dengan subyek hukum yang lain dalam lapangan hukum privat. Menurut Prins sebagaimana dikutip oleh Safri Nugraha dkk, " tindakan hukum privat dilarang bagi administrasi negara bila tujuan yang dimaksud dapat juga dicapai dengan jalan hukum publik." ${ }^{15}$ Hadjon sebagaimana dikutip oleh Safri Nugraha dkk, menguatkan bahwa dalam hal pemerintah membuat hubungan hukum dengan mesyarakat baik orang perorangan maupun badan hukum privat, sangat dimungkinkan terdapat ketentuan hukum publik (hukum administrasi negara/hukum tata usaha negara) yang memberikan pengaruh terhadap hukum privat. Sebagai contoh, dalam pengadaan barang dan jasa, pemerintah harus tunduk pada mekanisme yang diatur dalam peraturan tentang pengadaan. ${ }^{16}$ Di sisi lain, Van Wijk dan Konijnnebelt berpendapat, kemudian dikuatkan oleh Paul Scholten dan dimodifikasi oleh Wiarda, pada pokoknya, pemerintah dalam membuat hubungan hukum dengan masyarakat tidak dilarang untuk menggunakan hukum perdata, selama tidak bertentangan dengan hukum publik dan asas umum pemerintahan yang baik. ${ }^{17}$

Setidaknya ada 4 (empat) jenis perjanjian yang biasa digunakan oleh pemerintah, yaitu: perjanjian perdata biasa, perjanjian mengenai wewenang pemerintahan, perjanjian mengenai kebijakan yang akan dilaksanakan, dan perjanjian mengenai jual beli barang dan jasa. ${ }^{18}$ Perjanjian perdata biasa merupakan jenis perjanjian yang paling sering dibuat oleh pemerintah. Pada perjanjian perdata biasa, dibuat oleh pemerintah berdasarkan kewenangan yang dimiliki. Dengan demikian setiap perjanjian yang dibuat oleh pemerintah selalu didahului dengan adanya suatu Keputusa Tata Usaha Negara (KTUN) untuk melakukan suatu tindakan dalam lapangan hukum perdata atau yang lain, yang menjadi dasar dibuatnya perjanjian. ${ }^{19}$

Dalam konteks kerjasama daerah, yang mekanismenya telah diatur dalam Permendagri Nomor 22 Tahun 2009 tersebut di atas, pada Lampiran I Permendagri terdapat tahapan-tahapan yang memuat prinsip-prinsp dasar kerjasama antara lain: tahapan persiapan, penawaran, dan pensiapan penandatanganan kesepakatan penawaran harus berdasarkan kewenangan dan prosedur, maka kerjasama pada tahap tersebut tunduk pada hukum administrasi (hukum publik). Sementara, penandatangan perjanjian, dan pelaksanaan 
kerjasama tunduk pada Kitap Undang-Undang Hukum Perdata (hukum privat). ${ }^{20}$

Mendasarkan pada penjelasan di atas, kerjasama daerah yang dibuat dengan melibatkan pemerintah daerah sebagai salah satu pihak dalam perjanjian, dengan manapun ia mengikatkan diri dalam suatu perjanjian, baik dengan pemerintah daerah lain, pihak ketiga, pemerintah daerah di luar negeri, maupun lembaga di luar negeri, terikat pada ketentuan PP Nomor 28 Tahun 2018 tentang Kerja Sama Daerah. Konsekuensi dari terlibatnya administrasi negara atau pemerintah dalam pembuatan perjanjian, maka akan terikat pada ketentuan hukum publik yang mengatur sebagai dasar dari perbuatan tersebut, karena peraturan pemerintah bersifat imperatif.

\section{Hakikat Memorandum Of Understanding (Mou) dalam Perjanjian Kerjasama Daerah}

Pasal 1 Peraturan Pemerintah Nomor 28 tahun 2018 memberikan definisi tentang Kerja Sama Daerah adalah usaha bersama antara daerah dan daerah lain, antara daerah dan pihak ketiga, dan/atau antara daerah dan lembaga atau pemerintah daerah di luar negeri yang didasarkan pada pertimbangan efisiensi dan efektivitas pelayanan publik serta saling menguntungkan. Berdasarkan PP Nomor 28 tahun 2018, ini Kerjasama Daerah dapat dibedakan menjadi:

a. Kerja Sama Daerah Dengan Daerah Lain, yang selanjutnya disingkat KSDD adalah usaha bersama yang dilakukan oleh daerah dengan daerah lain dalam rangka penyelenggaraan urusan pemerintahan yang menjadi kewenangan daerah untuk kesejahteraan masyarakat dan percepatan pemenuhan pelayanan publik.

b. Kerja Sama Daerah Dengan Pihak Ketiga, yang selanjutnya disingkat KSDPK adalah usaha bersama yang dilakukan oleh daerah dengan pihak ketiga dalam rangka penyelenggaraan urusan pemerintahan yang menjadi kewenangan daerah untuk meningkatkan kesejahteraan masyarakat dan percepatan pemenuhan pelayanan publik.

c. Kerja Sama Daerah Dengan Pemerintah Daerah di Luar Negeri, yang selanjutnya disingkat KSDPL adalah usaha bersama yang dilakukan oleh daerah dengan pemerintah daerah di luar negeri dalam rangka penyelenggaraan urusan pemerintahan yang menjadi kewenangan daerah untuk meningkatkan kesejahteraan masyarakat dan percepatan pemenuhan pelayanan publik.

d. Kerja Sama Daerah Dengan Lembaga di Luar Negeri, yang selanjutnya disingkatKSDLLadalahusahabersama yang dilakukan oleh daerah dengan lembaga di luar negeri dalam rangka penyelenggaraan urusan pemerintahan yang menjadi kewenangan daerah untuk meningkatkan kesejahteraan masyarakat dan percepatan pemenuhan pelayanan publik.

Selanjutnya dalam Pasal 2 PP Nomor 28 tahun 2018 disebutkan bahwa: (1) Dalam pelaksanaan KSDD, daerah diwakili oleh gubernur atau bupati/wali kota yang bertindak untuk dan atas nama daerah; dan (2) Gubernur atau bupati/wali kota sebagaimana dimaksud pada ayat (1) dapat memberikan kuasa kepada pejabat di lingkungan perangkat daerah untuk menandatangani perjanjian kerja sama. Dalam penyelenggaraan kerjasama daerah, para pihak diikat dengan sebuah perjanjian kerjasama. Perjanjian ini dituangkan dalam bentuk tertulis. Sebelum membuat perjanjian, ada tahapan yang harus dipenuhi sebagai mana diamanatkan oleh Peraturan Pemerintah No. 28 Tahun 2018 Tentang Kerjasama Daerah.

Pasal 6 ayat (1) Peraturan Pemerintah No. 28 Tahun 2018 Tentang Kerjasama Daerah yang 
menyatakan bahwa Penyelenggaraan KSDD dilakukan melalui tahapan:
a. persiapan;
b. penawaran;
c. penyusunan kesepakatan bersama;
a. penandatanganan kesepakatan bersama;
b. persetujuan Dewan Perwakilan Rakyat Daerah;
c. penyusunan perjanjian kerja sama;
d. penandatanganan perjanjian kerja sama;

Dalam peraturan tersebut dinyatakan bahwa adatahapanberupapenyusunandanpenandatanganan kesepakatan bersama. Kesepakatan bersama dalam praktik lebih sering dikenal dengan sebutan Memorandum Of Understanding (MoU). Dalam praktiknya, perjanjian kerjasama daerah dilakukan oleh dinas-dinas yang bersangkutan secara langsung, padahal pemerintah kota harus tahu breakdown dari perjanjian tersebut, apa objeknya, ruang lingkupnya dan dinas mana saja yang terkait, sehingga kepala daerah tahu keseluruhannya selaku kepala daerah. Apabila langsung perjanjian kerjasama daerah, kepala daerah tidak tahu karena langsung antar OPD, sedangkan kalau MoU harus ditandatangani oleh kepala daerah. Oleh karenanya, MoU ini sebagai alat pemerintah daerah untuk mengetahui keseluruhannya, karena dari 1 (satu) MoU dapat diturunkan menjadi beberapa perjanjian kerja sama. ${ }^{21}$

Berkenaan dengan dibuat atau tidaknya MoU sesungguhnya tidak memiliki konsekuensi yang berarti, karena MoU hanya sebagai pemandu/ payung hukum/keran pembuka untuk dilakukannya perjanjian kerjasama daerah. Intinya, adanya MoU agar Kepala Daerah dapat mengetahui dan meminimalisir terjadinya permasalahan dikemudian hari dalam penyelenggaraan kerjasama daerah. ${ }^{22}$

Keberadaan MoU sebelum membuat perjanjian kerjasama daerah dianggap lebih efektif karena setiap penyelenggaraan kerja sama itu Kepala Daerah harus mengetahui. MoU juga memberikan kepastian hukum bagi para pihak dalam hubungan hukum mereka karena memiliki jangka waktu, yaitu setelah 12 (dua belas) bulan sejak ditandatanganinya MoU harus sudah ada tindak lanjut denagn mebuat perjanjian kerjasama daerah. Selain itu, dengan MoU bisa merangkul dinas-dinas yang minat atau ingin melakukan kerja sama. ${ }^{23}$

Berdasarkan pemaparan dari narasumber dapat dilihat bahwa keberadaan MoU memiliki fungsi kontrol terhadap penyelenggaraan kerjasama daerah. Kepala Daerah memiliki peran untuk mengawasi agar setiap perjanjian yang dibuat oleh instansi pelaksana telah sesuai dengan aturan atau prosedur yang berlaku. Berkaitan dengan syarat adanya MoU dalam kerjasama daerah haruslah dibedakan dengan sifat tidak mengikatnya MoU. MoU yang dibuat dalam rangka kerjasama daerah tidaklah kehilangan sifatnya yang tidak mengikat, bahkan dalam implementasinya pun terdapat $\mathrm{MoU}$ yang dibuat oleh daerah namun tidak ditindaklanjuti dengan perjanjian kerjasama. Dalam hal ini tidak ada dampak hukum yang terjadi, namun selayaknya menjadi perhatian dan evaluasi bagi daerah dalam menginisiasi kerjasama dengan pihak lain haruslah mempertimbangkan keseriusan dan itikad baik untuk menjalin kerjasama.

Di sisi lain, wajib hadirnya MoU mekanisme kerjasama daerah sebagaimana diatur dalam ketentuan PP Nomor 28 tahun 2018 bukanlah tanpa makna. Pada tataran implementasi, terafirmasi dari Pemerintah Daerah yeng menyelenggarakan kerjasama daerah, bahwa kehadiran MoU sangatlah penting. MoU memiliki fungsi kontrol dari Kepala Daerah terhadap jenis-jenis perjanjian kerjasama yang dilaksanakan oleh OPD sebagai pelaksana teknis, karena setiap perjanjian kerjasama yang dibuat menginduk pada MoU. Selain itu, hadirnya MoU menjadi bukti bahwa penjajakan yang 
dilakukan oleh kedua belah pihak yang melakukan kerjasama telah dilakukan secara memadai, sehingga akan menyederhanakan dan mempermudah proses selanjutya, yaitu pembuatan perjanjian-perjanjian kerjasama.

\section{Kesimpulan}

Berdasarkan uraian pembahasan di atas, dapat disimpulkan 2 (dua) hal, yaitu: Pertama, Mou wajib dibuat sebagai syarat untuk dapat membuat perjanjian kerjasama daerah berdasarkan amanat Pasal 6 ayat (1) Peraturan Pemerintah No. 28 Tahun 2018 Tentang Kerjasama Daerah dimana salah satu tahapan yang harus dilalui adalah penyusunan dan penandatanganan kesepakatan bersama. Kedua, Secara konseptual dibuat atau tidaknya $\mathrm{MoU}$ sesungguhnya tidak memiliki konsekuensi yang berarti, karena MoU hanya sebagai pemandu/ payung hukum/keran pembuka untuk dilakukannya perjanjian kerjasama daerah. Keberadaan $\mathrm{MoU}$ memiliki fungsi kontrol dari Kepala Daerah terhadap penyelengaraan kerjasama daerah, mengingat hubungan hukum yang timbul dalam penyelenggaraan kerjasama daerah berdimensi publik yang didasarkan pada pertimbangan efisiensi dan efektivitas pelayanan publik serta saling menguntungkan para pihak.

\section{DAFTAR PUSTAKA}

\section{A. Buku}

Fajar, Mukti dan Achmad, Yulianto, 2013, Dualisme Penelitian Hukum Normatif dan Empiris, Pustaka Pelajar, Yogyakarta.

H.S, Salim, 2007, Perancangan Kontrak \& Memorandum of Understanding, Sinar Grafika, Jakarta.

Nugraha, Safri, et al., 2007, Hukum administrasi Negara, Center for Law and Good Governance Studies (CLGS) Fakultas Hukum Indonesia, Depok.

\section{B. Artikel Jurnal}

Meray Hendrik Mezak, 2006, Jenis, Metodedan Pendekatan Dalam Penelitian Hukum, Law Review. Fakultas Hukum Universitas Pelita Harapan, Vol. V, No.3. Maret 2006, Jakarta. Muhammad Yakim, "Kedudukan Hukum Pemerintah Daerah Dalam Kerjasama Daerah Dengan Pihak Ketiga", Jurnal Katalogis, Volume 5 Nomor 7, Juli 2017.

\section{Internet}

Prasetio, Bimo, et al., "Perbedaan antara Perjanjian dengan MoU", http://www.hukumonline.com/ klinik/detail/lt514689463d4b2/perbedaanantara-perjanjian-dengan-mou, diakses, 6 Maret 2018.

\section{Peraturan Perundang-Undangan}

Kitab Undang-Undang Hukum Perdata

Peraturan Pemerintah Republik Indonesia nomor 50 Tahun 2007 tentang Tata Cara Pelaksanaan Kerjasama Daerah (Lembaran Negara Republik Indonesia Tahun 2007 Nomor 112, Tambahan Lembaran Negara Republik Indonesia Nomor 4761).

Peraturan Pemerintah Nomor 28 Tahun 2018 tentang Kerja Sama Daerah (Lembaran Negara Republik Indonesia Tahun 2018 Nomor 97, Tambahan Lembaran Negara Republik Indonesia Nomor 6219).

Peraturan Menteri Dalam Negeri Nomor 22 Tahun 2009 Tentang Petunjuk Teknis Tata Cara Kerja Sama Daerah.

\section{E. Dokumen Lain}

Hasil wawancara dengan Ibu Tri Idawati, Kasub Kerja Sama Dalam Negeri, Pemda Surakarta, tanggal 3 September 2018. 